\title{
O uso da língua para a discriminação
}

\author{
Language usage for discrimination
}

\author{
Raquel Meister Ko. Freitag* \\ Universidade Federal de Sergipe \\ São Cristóvão, Sergipe, Brasil \\ Marcus Eugenio Oliveira Lima** \\ Universidade Federal de Sergipe \\ São Cristóvão, Sergipe, Brasil \\ Lucas Santos Silva** \\ Universidade Federal de Sergipe \\ São Cristóvão, Sergipe, Brasil \\ Victor Renê Andrade Souza ${ }^{* * * *}$ \\ Universidade Federal de Sergipe \\ São Cristóvão, Sergipe, Brasil
}

\begin{abstract}
Resumo: Analisamos uma postagem no Twitter do Ministro da Educação da República Federativa do Brasil que motivou a Procuradoria Geral da República a instaurar inquérito para apuração de crimes resultantes de preconceito e discriminação. No texto da postagem, sistematicamente o "r" é trocado por "l", em caixa alta. O conteúdo evoca as histórias da Turma da Mônica, cujo enredo gira em torno de "planos infalíveis" de Cebolinha e Cascão para derrotar Mônica. Por analogia, a China estaria envolvida em um plano conspiratório para disseminar a COVID-19. Demonstramos como a manipulação de um traço linguístico pode evocar discriminação e preconceito.
\end{abstract}

Palavras-chave: Preconceito. Discriminação. Sociolinguística. COVID-19.

\begin{abstract}
This paper analyzes a tweet by the Minister of Education of the Federative Republic of Brazil which motivated the Attorney General's Office to star an investigation for crimes resulting from prejudice and discrimination. In the tweet, systematically ' $r$ " is shifted for "l", in caps lock. The content evokes the stories of Monica and friends, whose are around the Cebolinha and Cascão' "infallible plans" to defeat Monica. By analogy, China would be involved in a conspiratorial plan to spread the COVID-19. The paper shows how the manipulation of a linguistic trait can evoke discrimination and prejudice.
\end{abstract}

Keywords: Prejudice. Discrimination. Sociolinguistic. COVID-19.

\footnotetext{
* Doutora em Linguística pela Universidade de Santa Catarina (UFSC), professora da Universidade Federal de Sergipe (UFS), São Cristóvão/SE. Bolsista de Produtividade em Pesquisa do CNPq. E-mail: rkofreitag@uol.com.br.

** Doutor em Psicologia Social pelo Instituto Superior de Ciências do Trabalho e da Empresa (ISCTE-PT), professor da Universidade Federal de Sergipe (UFS), São Cristóvão/SE. E-mail: marcuseolima@gmail.com. *** Mestrando em Letras pela Universidade Federal de Sergipe (UFS). Bolsista Capes. E-mail: lucas_riachao@hotmail.com.

**** Mestrando em Letras pela Universidade Federal de Sergipe (UFS). Bolsista Capes. E-mail: victor.andrade573@gmail.com.
} 


\section{INTRODUÇÃO}

Conhecida como Marco Civil da internet, a Lei 12.965, de 23 de abril de 2014, estabelece princípios, garantias, direitos e deveres para o uso da internet no Brasil (BRASIL, 2014). Em seu artigo $2^{\circ}$ destaca como princípio fundamental o respeito à liberdade de expressão, que já é garantida na Constituição Federal de 1988, no inciso IV, do artigo $5^{\circ}$ : "é livre a manifestação do pensamento, sendo vedado o anonimato" e no inciso IX: "é livre a expressão da atividade intelectual, artística, científica e de comunicação, independentemente de censura ou licença” (BRASIL, 1988).

Há, no entanto, exceções. A Lei 7.716, de 5 de janeiro 1989, já em seu artigo primeiro, determina que "Serão punidos, na forma desta Lei, os crimes resultantes de discriminação ou preconceito de raça, cor, etnia, religião ou procedência nacional" (BRASIL, 1989). Neste ano, esta lei tem sido evocada, como na demissão do Ministro José Alvim, em 17 de janeiro, por "apologia ao nazismo". E, mais recentemente, no pedido de instauração de inquérito 4827, de 14 de abril de 2020, pela Procuradoria Geral da República.

As mencionadas peças de informação revelam que o Ministro de Estado da Educação, Abraham Bragança de Vasconcellos Weintraub, teria veiculado no dia 4 de abril próximo passado, e posteriormente apagado, manifestação depreciativa com a utilização de elementos alusivos à procedência do povo chinês, no perfil que mantém na rede social Twitter. Esse comportamento configura, em tese, a infração penal prevista na parte final do art. 20 da lei $\mathrm{n}^{\mathrm{o}} 7.716 / 1989$, que define os crimes resultantes de preconceito.

Em meio à pandemia da COVID-19, o Ministro da Educação, Abraham Weintraub, muito ativo nas redes sociais, postou no Twitter um comentário, seguido de uma ilustração de uma capa da revista $A$ turma da Mônica (Figura 1).

Figura 1: Postagem do perfil do Ministro da Educação do dia 5 de abril de 2020 no Twitter

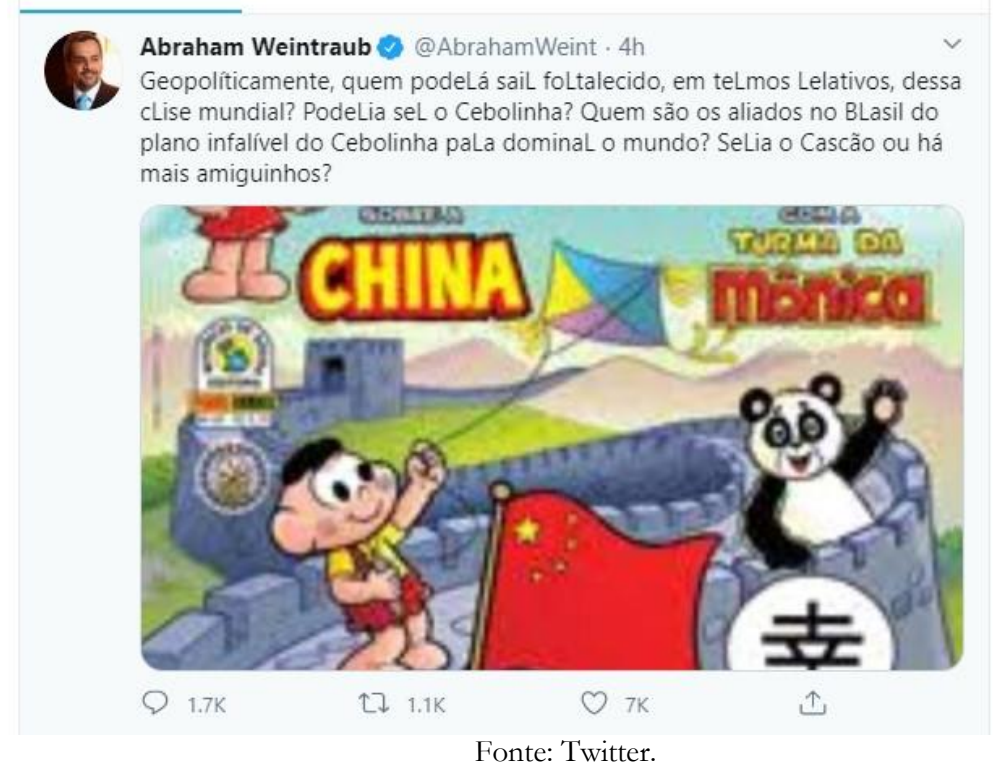


Esta postagem, segundo a Procuradoria Geral da República, faz jus à aplicação do artigo 20 da Lei 7.716, de 5 de janeiro 1989, que determina punição para quem "Praticar, induzir ou incitar a discriminação ou preconceito de raça, cor, etnia, religião ou procedência nacional" (BRASIL, 1989). Diferentemente de um assassinato ou de um assalto, crimes de discriminação e preconceito não tem uma materialidade evidente. Materialmente, na postagem do Ministro da Educação há apenas o uso indevido da ilustração, sem reconhecimento de direitos autorais, uma infração à Lei 9.610, de 19 de janeiro de 1998, acerca da proteção da propriedade intelectual, que é pouco aplicada dada a amplitude da demanda na internet.

Para embasar um crime de discriminação e preconceito, é preciso primeiramente conceituar o que são preconceito e discriminação e examinar como eles se manifestam, para depois, descontruir o estereótipo subjacente que os motiva. E, neste caso específico, como a manipulação de um traço da língua se transforma em mecanismo para o preconceito.

\section{PRECONCEITO, ESTEREOTIPIA E INDEXICALIDADE LINGUÍSTICA}

Allport (1954/1979) define o preconceito como uma antipatia baseada numa generalização falha e inflexível, que pode ser sentida ou expressa e que pode ser dirigida a um grupo como um todo ou a um indivíduo porque ele faz parte daquele grupo. É possível destacar nessa definição duas características principais: i) o preconceito é uma espécie de defeito cognitivo (uma generalização falha e inflexível), e ii) o preconceito é uma atitude (antipatia) que pode ser sentida (emoção) ou externalizada (comportamento discriminatório). O perpetrador do preconceito toma o seu próprio grupo de pertencimento como ponto de referência positivo para se comparar com o grupo do outro (JONES, 1972). A manifestação comportamental do preconceito é a discriminação, entendida como ações que negam a indivíduos ou a grupos igualdade de acessos e de tratamento, criando, mantendo ou reforçando um sistema de vantagens ou privilégios de um grupo em detrimento de outro (DOVIDIO et al., 2010).

As definições mais modernas propõem que preconceito é uma atitude negativa dirigida contra um grupo como um todo ou contra seus membros (STANGOR, 2009), ou, ainda, que são ideologias, atitudes e crenças que ajudam a manter e legitimar as hierarquias e a exploração social (SIBLEY; BARLOW, 2018). O preconceito é uma atitude-em-contexto que expressa uma avaliação desfavorável a pessoas que são estereotipadas de uma forma incompatível com os atributos requeridos para um determinado papel ou função social. Ou seja, o preconceito se manifesta na intersecção entre os estereótipos e os papéis sociais dos grupos em cada contexto (EAGLY; DIEKMAN, 2008).

Em termos de etiologia do preconceito, podemos considerar vários níveis ou planos explicativos, todos complementares. Num nível individual há várias explicações para as causas do preconceito. Uma delas é a Teoria da Personalidade Autoritária, que postula ser o preconceito a expressão de uma necessidade interna gerada por uma personalidade patológica forjada na primeira infância através de experiências de socialização com pais 
severos, que, entretanto, eram admirados de forma excessiva e não crítica. Tais experiências de socialização criariam um "estilo cognitivo" na vida adulta. Tal estilo seria alimentado pelo mecanismo psicológico da repressão de todos os desejos que pudessem gerar vergonha e culpa. Para descarregar esses afetos "vergonhosos", o indivíduo com personalidade autoritária escolheria "bodes expiatórios", construindo via projeção (outro mecanismo psicanalítico) uma imagem de que os outros são pecadores, descontrolados, sujos, pervertidos, ou seja, culpados das próprias culpas que corroem a personalidade doentia do autoritário (ADORNO et al. 1950). Tal personalidade, por ser incapaz de estabelecer relações íntimas autênticas, se vincularia ao mundo de forma artificial, construindo figuras míticas e heroicas, objetos de cultos e, por outro lado, figurações fantasiosas de inimigos ou traidores (BILLIG, 1984).

No nível dos processos coletivos, um exemplo de explicação da etiologia do preconceito é a percepção de que o grupo do outro (exogrupo) é uma ameaça ao meu grupo (endogrupo). A Teoria Integrada da Ameaça (STEPHAN; STEPHAN, 2000) propõe que as vítimas de preconceito vivem um tipo de "cerco" na sociedade, sitiados em contextos de relações que desencadeiam quatro tipos de percepções/sentimentos: a ameaça real, a ameaça simbólica, a ansiedade intergrupal e os estereótipos negativos. A ameaça real decorre das teorias do conflito concreto, nela predominam as preocupações com danos físicos, segurança ou perda de recursos materiais. A ameaça simbólica se refere à preocupação com a integridade ou validade do sistema de significados e valores. Ou seja, decorre da percepção de que o outro (ameaçador) pode invalidar ou "contaminar" as visões de mundo do meu grupo, da minha cultura. Essa percepção estruturaria aquilo que a literatura psicossocial chama de "novas formas" de preconceito (LIMA; VALA, 2004). A ansiedade intergrupal, terceiro tipo de ameaça destacada na teoria, se refere ao estado de desconforto emocional que as interações com o exogrupo geram. Finalmente, os estereótipos negativos são um mecanismo de diferenciação do endogrupo em relação ao exogrupo (estigmatizado); de forma que o endogrupo é mais descrito em termos de características de valência positiva e conteúdo humanizador, enquanto o exogrupo seria descrito de forma menos positiva e mais infra-humanizadora.

Em suma, i) preconceito é uma atitude hostil e ii) se dirige a um indivíduo ou grupo/categoria social. Atitude é a classificação de um objeto social em uma dimensão avaliativa, com base em três dimensões de informação: cognitiva, afetiva e comportamental (ZANNA; REMPEL, 1988). É uma forma uma organização relativamente duradoura de crenças (estereótipos), geralmente dotada de carga afetiva contra algum objeto social, que predispõe a uma ação (discriminação) coerente com as cognições e afetos relativos a esse objeto (RODRIGUES; ASSMAR; JABLONSKI, 1999).

Estereótipos são entendidos classicamente como "pictures in our heads" (LIPPMANN, 1922), ou seja, como um conjunto de características que são mentalmente associadas com uma etiqueta ou rótulo grupal (STANGOR; LANGE, 1994). Ou, ainda, como estruturas cognitivas que contêm nossos conhecimentos e expectativas, e determinam nossos juízos e avaliações sobre os grupos humanos e seus membros (HAMILTON; TROLIER, 1986). Ou simplesmente como traços que surgem na nossa mente quando nós pensamos sobre os grupos sociais (STANGOR, 2000). 
Estereótipos precisam ser ativados. Uma das formas de ativação de estereótipos se dá por meio da indexicalidade resultante da associação entre traços linguísticos e grupos sociais, a indexicalidade, é, portanto, uma propriedade da língua que permite a constituição de significados sociais baseados em práticas e traços linguísticos, mobilizando categorias como gênero, cor, classe, etnicidade (OCHS, 1992).

Os significados, assim indexados, implicam em ideologias linguísticas. É o que acontece no processo de mock language, um conceito da Antropologia Linguística que se refere ao uso intencional de uma língua não falada ou não materna de um falante que é manipulada para demonstrar a esse falante a ideologia linguística de uma língua hegemônica. Este conceito é proposto por Hill (1998), para o Spanish mock, com a apropriação de traços linguísticos presumidos de um grupo por outro, o hegemônico. Um exemplo claro seria "Hasta la vista, baby", frase famosa do filme Exterminador do Futuro. O uso de palavras do espanhol por falantes de inglês com o objetivo de demonstrar a superioridade do inglês configura-se como uma apropriação, com viés racista.

Silva $(2019$, p. 2), a partir do conceito de mock language, propõe a caracterização do "português de arremedo" entre brasileiros, o que seria uma "prática linguística na qual uma pessoa replica palavras e expressões de variedades não padrão - consideradas erradas, segundo a norma culta - com o intento de fazer graça". A manipulação deliberada da variação linguística no português brasileiro funciona como recurso para piadas. $\mathrm{O}$ autor explica que o recurso do português de arremedo é utilizado nas histórias em quadrinhos da Turma do Chico Bento, em que traços linguísticos presentes nas falas dos personagens relacionam-se aos perfis sociais a que representam. O personagem Chico Bento representaria o falar "caipira", um estereótipo construído e com traços linguísticos associados a ele, embora não exclusivos (AMARAL, 1976); o primo de Chico Bento, por sua vez, marca o falar urbano, de prestígio. Silva (2019) argumenta que o português de arremedo produz uma falsa sensação de inocuidade, por se manifestar por meio da piada, e a pessoa que o produz ocupa um lugar de fala que é resultado de desigualdade linguística e social; ainda, essa pessoa é, em parte, responsável pela reprodução dessa desigualdade.

Estereotipia e a indexicalidade são processos que dão base ao preconceito e à discriminação, como demonstraremos na postagem do Ministro da Educação.

\section{ESTEREOTIPIA E A MANIPULAÇÃO DA LÍNGUA PARA O PRECONCEITO}

Qual é a "manifestação depreciativa" na postagem do Ministro da Educação que motivou a Procuradoria Geral da República a instaurar inquérito para apuração de crimes resultantes de preconceito? A manifestação da Procuradoria Geral da República não é sem razão: logo em seguida, na mesma rede social, o perfil da Embaixada da China no Brasil se manifesta em resposta, apontando a estigmatização da China e o "cunho fortemente racista" (Figura 2). 
Figura 2: Postagem do perfil da Embaixada da China no Brasil do dia 6 de abril de 2020 no Twitter

Embaixada da China no Brasil
@EmbaixadaChina
Manifestação do Porta-Voz da Embaixada da China
no Brasil sobre Declarações anti-China Feitas
pelo Membro do Governo Brasileiro
Em 5 de abril, o Ministro da Educação do Brasil Abraham
Weintraub, ignorando a posição defendida pela parte
chinesa em diversas gestões, fez declarações difamatórias
contra a China em redes sociais, estigmatizando a China ao
associar a origem da coviD-19 ao país. Deliberadamente
elaboradas, tais declarações são completamente absurdas e
desprezíveis, que têm cunho fortemente racista e objetivos
indizíneis, tendo causado influências negativas no
desenvolvimento saudável das relações bilaterais China-
Brasil. O lado chinês manifesta forte indignação e repúdio a
esse tipo de atitude.
Atualmente, a pandemia da Covid-19 está se espalhando
globalmente, trazendo um desafio que nenhum país
consegue enfrentar sozinho. A maior urgência neste
momento é unir todos os países numa proativa cooperação
internacional para acabar com a pandemia com a maior
brevidade. com vistas a salvaguardar a saúde bública
44,8 mil 00:22 - 6 de abr de 2020
$\quad$ Fonte: Twitter.

Para entendermos a estigmatização da China, precisamos reconstruir os processos que subjazem ao preconceito. A compreensão da postagem depende do acesso a conhecimentos prévios compartilhados que possibilitem a comparação entre os chineses (ou a China) e o Cebolinha, dois referentes ativados nesta postagem, e em ambos os casos, há um efeito de que o exogrupo é uma ameaça ao endogrupo, real e simbólica. $\mathrm{Na}$ construção do referente China, ao associar a origem da pandemia ao lugar ("vírus chinês"), rótulo empregado nos Estados Unidos pelo presidente Donald Trump e replicado pelo presidente do Brasil, o endogrupo atribui ao exogrupo uma ameaça material ("crise mundial”, ameaça à segurança e à integridade física face pela pandemia), de natureza intencional e conspiratória ("aliados"). ${ }^{1} \mathrm{Na}$ construção do referente Cebolinha, o conteúdo evoca as histórias da Turma da Mônica, cujo enredo gira em torno de "planos

\footnotetext{
${ }^{1}$ Circulam notícias de que o "vírus chinês" foi desenvolvido em laboratório e disseminado deliberadamente, inclusive com endosso de autoridades científicas $<$ https://istoe.com.br/Novo-coronavIrus-foi-fabricadoem-laboratorio-chines-diz-descobridor-do-HIV $>$, as quais já foram objeto de agências de checagem, e até $\mathrm{o}$ presente momento, não há evidência em favor < https://noticias.uol.com.br/confere/ultimasnoticias/2020/03/30/coronavirus-nao-foi-criado-em-laboratorio-pelo-partido-comunista-da-china.htm $>$
} 
infalíveis" de Cebolinha e Cascão para derrotar Mônica, novamente uma relação de ameaça material do exogrupo ao endogrupo. Por analogia, os chineses estariam envolvidos em um plano conspiratório para disseminar a epidemia (Figura 3).

A ameaça simbólica está ativa no referente China; é decorrente da percepção de que o exogrupo pode invalidar ou "contaminar" as visões de mundo do endogrupo, uma ameaça do "comunismo" ao "capitalismo", uma das novas formas de preconceito (LIMA; VALA, 2004). O que liga os dois referentes e ativa os estereótipos é a troca do R pelo L, um traço linguístico, que é evocado para ativar o preconceito, que é decorrente das associações de valência negativa e depreciativa que estão associadas ao exogrupo.

Figura 3: Comparação estabelecida a partir da troca de /r/ por /1/

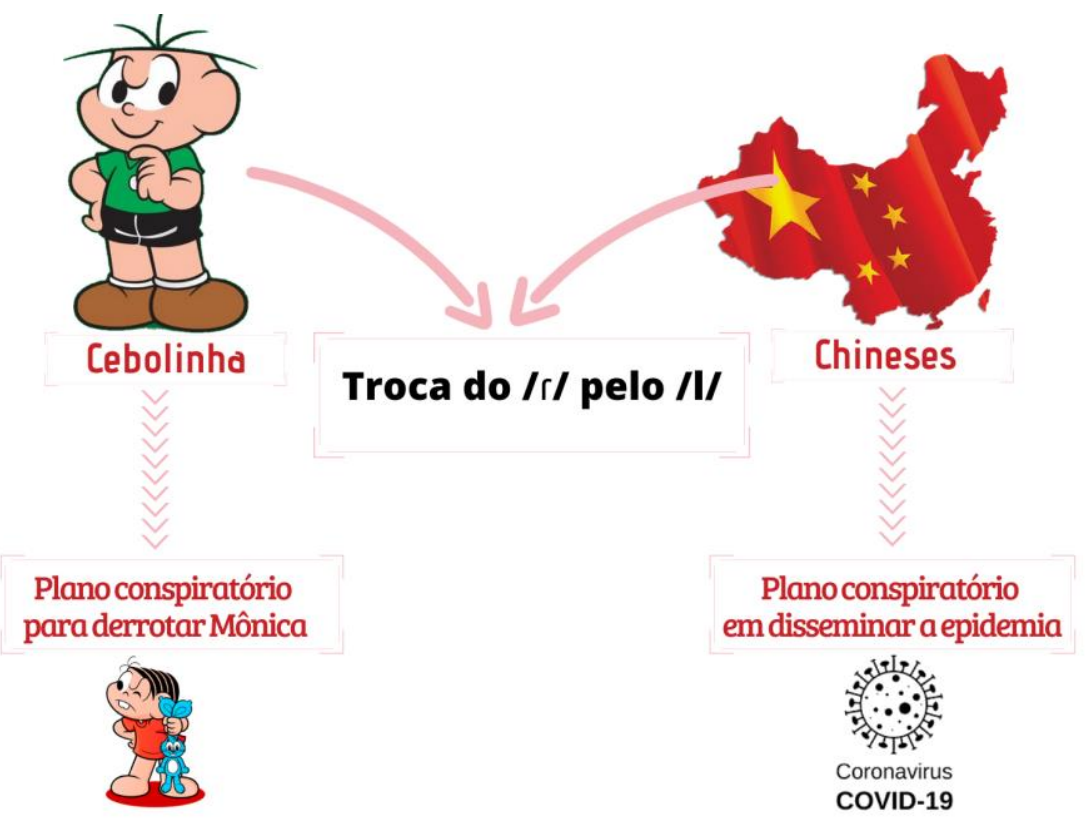

Fonte: Os próprios autores.

O objetivo da Constituição República Federativa do Brasil, segundo o inciso IV do artigo $3^{\circ}$, é "promover o bem de todos, sem preconceitos de origem, raça, sexo, cor, idade e quaisquer outras formas de discriminação" (BRASIL, 1988). Uma forma de discriminação, sutil e perversa, é o preconceito linguístico. Não seria a primeira vez que o Ministro da Educação incorreria neste tipo de preconceito: sua postagem de 17 de fevereiro deste ano, por exemplo, deliberadamente (Espero que dessa forma a notícia chegue a todos) manipula a escrita, articulando erros ortográficos (como em Oje e paçado) e traços contínuos da fala transpostos para a escrita (o alçamento da vogal média a alta em intregamos) (Figura 4). 
Figura 4: Postagem do perfil do Ministro da Educação do dia 17 de fevereiro de 2020 no Twitter

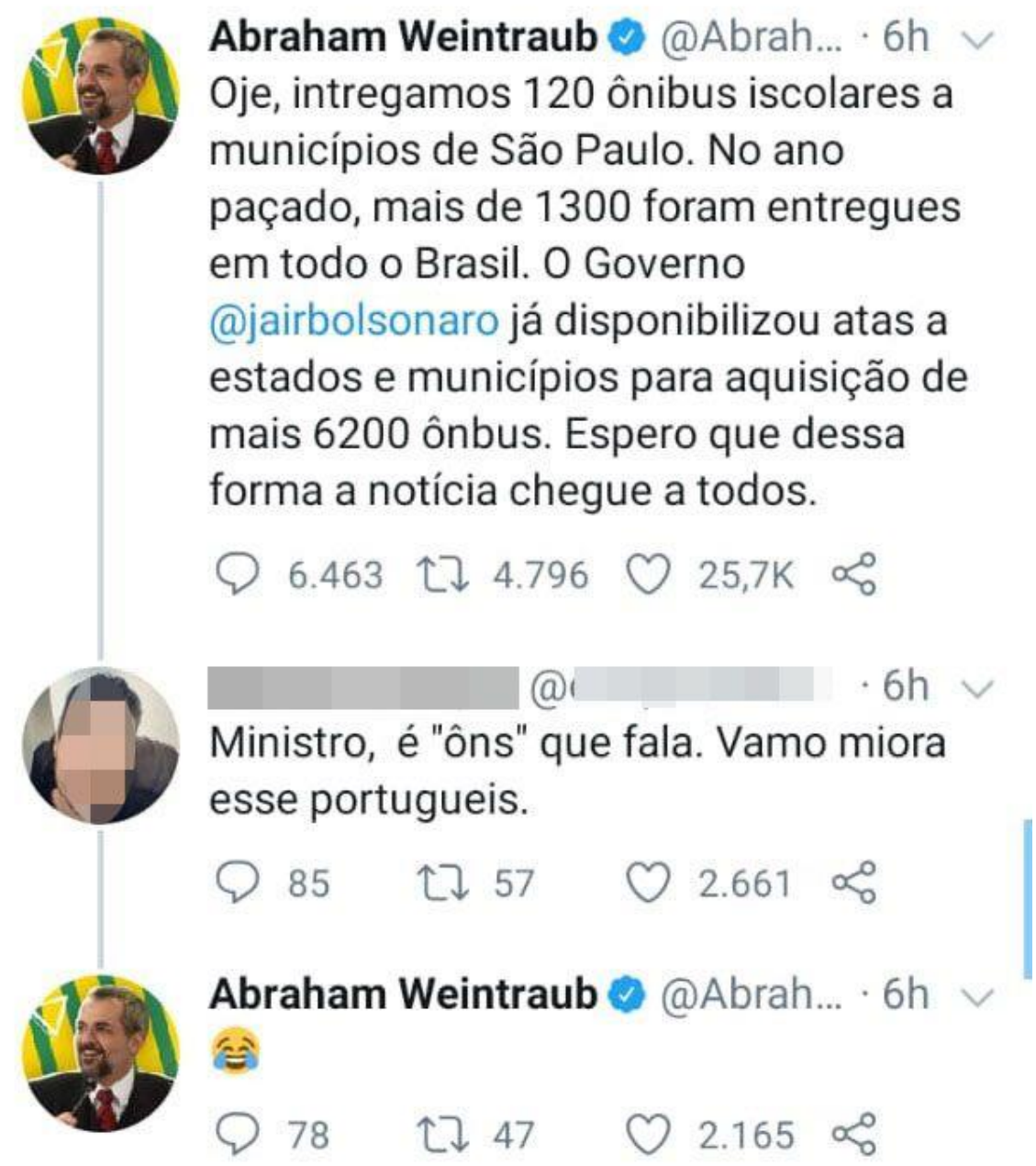

Fonte: Twitter.

A postagem teve adesão, como no comentário de um seguidor, que, além de sugerir uma "correção" (ônibus para ôns), segue a linha da transposição de traços da fala para escrita, ditongando português, apagando o -s de vamos e o -r no infinitivo melhorar, que também sofre alçamento e iotização. Todos estes processos acontecem na fala, inclusive de pessoas letradas e escolarizadas, são traços contínuos, conforme Bortoni-Ricardo (2004); no entanto, foram manipulados para atingir as pessoas a quem a notícia não chega, o universo não escolarizado ou particularmente escolarizado. 
Figura 5: Repercussão da postagem do Ministro da Educação do dia 17 de fevereiro de 2020 no Twitter

Pp Reaca RN \#ForaMaia $\bigcirc$ O mito @AbrahamWeint faz uma zoação. As antas, os Marinho e o voz fina caem igual patinho kkkkk

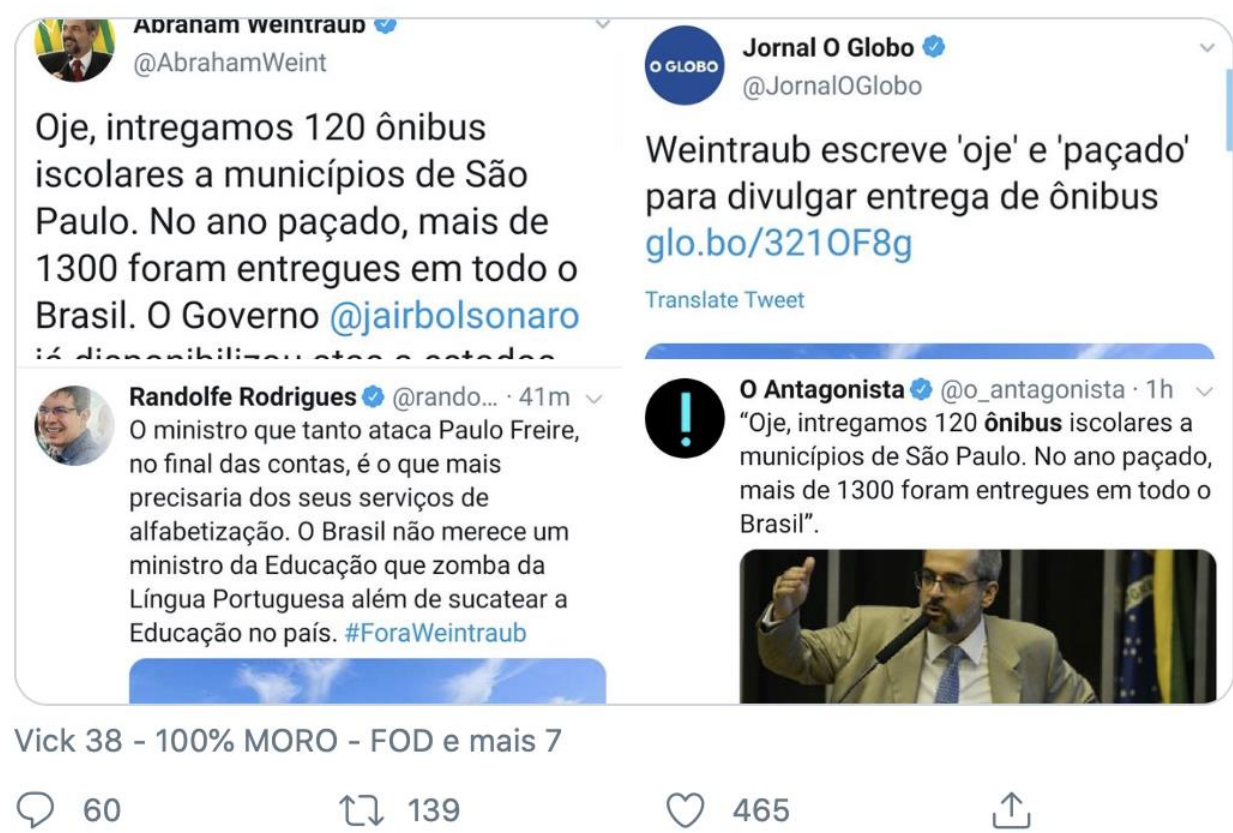

Fonte: Twitter.

Esta postagem, explícita e deliberadamente manipulada, como confirma a postagem de um seguidor "comemorando" (Figura 5), parece ser uma resposta às críticas recebidas por outras, em que o Ministro da Educação cometeu erros de ortografia (escreveu imprecionante por impressionante; suspenção por suspensão, paralização por paralisação) e foi alvo de piadas (“o Ministro da Educação não sabe português"...). ${ }^{2}$

Há quem argumente que os ministros estão sendo alvo de preconceito linguístico; o fato é que erraram, e estão sendo avaliados por isso. Situação diferente da postagem do Ministro da Educação, que usa um traço linguístico para estigmatizar um grupo. O mesmo ocorre com a postagem que inicia este texto.

2 Ver, por exemplo: < https://noticias.r7.com/prisma/portugues-de-brasileiro/um-erro-imprecionanteuma-paralizacao-do-portugues-09012020>

$<$ https://www.em.com.br/app/noticia/internacional/2020/01/10/interna internacional,1113629/minist ro-da-educacao-e-alvo-de-piadas-por-erros-de-portugues-nas-redes.shtml $>$. O Ministro da Educação não foi o primeiro membro do governo a virar piada por seus usos linguísticos. O Ministro da Justiça, por exemplo, além de realizar síncope, flexionou a palavra cônjuge, que, nos dicionários, é uma palavra masculina (PINHEIRO; FREITAG, 2020): “A possibilidade, por exemplo, de uma mulher, uma conje, seja morta pelo seu conje" $(<\underline{\text { https://tv.uol/17mjX. }}>$ ). 
Para demonstrar o preconceito aos não escolarizados evocado pelos traços linguísticos manipulados na postagem, a Sociolinguística brasileira tem um amplo conjunto de trabalhos descritivos que sistematizam a variação e explicam os contextos em que ela ocorre ${ }^{3}$. Para demonstrar o gatilho do preconceito contra a China e, por tabela, ao povo chinês, gerando discriminação, é preciso explicar: i) a manipulação do uso linguístico associado ao Cebolinha, e a sua troca de R por L; e ii) a crença de que chineses (na verdade, orientais de maneira geral) que aprendem português trocam $\mathrm{R}$ por L, considerando estudos fonológicos e de aquisição de L2.

\subsection{CEBOLINHA E A TROCA DO “R” PELO “L}

"Cascão" e "Cebolinha" são personagens da Turma da Mônica, uma série de histórias em quadrinhos criada por Maurício de Sousa, cuja origem remonta o ano de 1959, em tiras publicadas em jornal, e na década de 1970 em revistas em quadrinhos. A "turma" é composta por personagens infantis urbanas (mais recentemente, foi lançada a Turma da Mônica Jovem, mostrando a versão adolescente) cujas histórias, baseadas no cotidiano, garantiram a vitalidade e amplitude da marca Turma da Mônica na cultura brasileira. Não é isenta de estereótipos: Cebolinha é o menino valentão em eterno conflito com a menina Mônica; as histórias giram em torno de um plano infalível dos meninos para roubar o coelhinho Sansão, objeto querido de Mônica. No entanto, o plano sempre dá errado e a menina Mônica se vinga fisicamente, usando o coelhinho como instrumento para deixar os meninos de olho roxo.

As histórias em quadrinho de Maurício de Sousa, não só a Turma da Mônica, mas as outras turmas, como a Turma do Chico Bento, estão presentes também na escola, sendo amplamente utilizadas em materiais didáticos nas aulas de língua portuguesa (BORTONIRICARDO, 2004; COAN; FREITAG, 2010; SILVA; SIMIONI, 2016, dentre outros).

Atualmente, as histórias têm se alinhado a demandas politicamente corretas, substituindo a misoginia e a violência presentes nas histórias originais pela inclusão e a diversidade. ${ }^{4}$ E é pelo prisma da diversidade e inclusão que o personagem Cebolinha deve

\footnotetext{
${ }^{3}$ Destacamos as coletâneas chanceladas pelo Grupo de Trabalho de Sociolinguística da Associação Nacional dos Programas de Pós-Graduação em Letras e Linguística (ANPOLL) que tratam do mapeamento do português brasileiro, assim como os textos de retrospectiva (PAIVA; SCHERRE, 1999; RONCARATI; ABRAÇADO, 2003; 2008; SCHERRE, 2012; ABRAÇADO; MARTINS, 2015; FREITAG, 2016).

${ }^{4}$ Em entrevista no Programa do Porchat, em 3 de maio de 2018, Maurício de Sousa explicou que as histórias da Turma da Mônica passaram por modificações, como a retirada de adjetivos "baixinha", "dentuça", "gorducha" para se referirem a Mônica; Cascão, que antes soltava balão, não solta mais; Cebolinha, ao invés de pintar diretamente no muro, agora pinta no papel e cola no muro. Além dessas modificações, novos personagens vêm sendo incorporados às histórias: Dorinha, cega, em 2004, em homenagem a Dorina Nowill, que também era cega e trabalhou para criação de leis e campanhas a favor dos deficientes visuais; também em Luca, personagem cadeirante, paraplégico, fã de Herbert Vianna (que, em acidente, ficou paraplégico) e inspirado nos atletas paraolímpicos; André, personagem características comportamentais do transtorno do espectro autista, que como tem olhos diferentes, não olha nos olhos de outras crianças, não as cumprimenta e não tem entusiasmo para brincadeiras (os demais não o excluem das brincadeiras e
} 
ser entendido. Uma das características da personagem Cebolinha, que inspirou a postagem do Ministro da Educação, é ter sua fala marcada pela troca da letra R pela letra L, numa tentativa de representar, graficamente, um fenômeno característico da fala de crianças com distúrbio articulatório, a dislalia, que consiste numa dificuldade articulatória na pronúncia de determinados sons da língua, podendo ocorrer por omissão, substituição, distorção ou acréscimo de sons às palavras (GHANDOUR; KADDAH, 2011; NOH et al. 2012; SOUZA; SILVA; COUTINHO, 2019). No português brasileiro, as alternâncias sonoras mais comuns são entre os sons [p] e [b], [f] e [v], [t] e [d], [r] e [1], [f] e [s], [3] e [z], []] e [s] (SOUZA; SILVA; COUTINHO, 2019). A alternância só é possível em contextos em que há proximidade articulatória.

$\mathrm{Na}$ fala de Cebolinha, os sons que se alternam correspondem ao grupo das consoantes líquidas, conjunto dos sons laterais e róticos que se agrupam "por padrões fonotáticos, como a possibilidade de formar ataque complexo com outra consoante, e pelo compartilhamento de fenômenos como, por exemplo, a vocalização, a metátese e o rotacismo" (COSTA, 2011, p. 16). Por estas similaridades, os sons laterais e róticos podem se neutralizar na fala. Dessa alternância, decorrem, pelo menos, dois fenômenos variáveis no português: o rotacismo e o lambdacismo.

O rotacismo consiste na neutralização do modo de articulação das consoantes líquidas, com a substituição da realização lateral [1] por tepe [r]. A neutralização ocorre porque, além do mesmo ponto, o modo de articulação das consoantes [1] e [r] são próximos. Enquanto na aproximante lateral alveolar [1] o ápice da língua é elevado em direção aos alvéolos, no tepe $[\mathrm{r}]$ ocorre um toque rápido no ápice da língua contra os alvéolos. Do ponto de vista sociolinguístico, no português brasileiro, o rotacismo ocorre sistematicamente em contexto de ataque complexo (bloco broco) e em coda silábica (calda carda) (GIORDANI, 2005; COSTA, 2007, 2013; FREITAG, et al., 2010; REIS, 2010; CASTRO, 2013; ROMANO; FONSECA, 2015, dentre outro). A variação entre [1] e [r] é um marcador sociodialetal do português brasileiro, recorrente na fala de regiões distantes dos grandes centros urbanos, de pessoas menos escolarizadas e mais velhas, sendo associado ao falar "caipira”. Na obra de Maurício de Sousa, a fala de Chico Bento, personagem da Turma do Chico Bento, é marcada por este traço.

A troca na fala de Cebolinha não é variação, e sim representação de um distúrbio articulatório da dislalia, o lambdacismo. A alternância entre as consoantes líquidas não ocorre livremente. Um rótico não alterna categoricamente com uma aproximante lateral, como faz parecer a fala de Cebolinha na postagem do Ministro da Educação ao trocar R por L em todos os contextos. A alternância entre as consoantes líquidas é condicionada por similaridades fonéticas. No português, percebe-se proximidades articulatórias entre a consoante lateral [1], a vibrante [r] e o tepe [r] (Cf. SILVA, 2005), o que viabiliza o processo

respeitam suas diferenças de atitude); e Tati, menina com síndrome de Down, inspirada em Tathiana Piancastelli. Maurício de Sousa afirmou que sempre buscou em seus personagens a representatividade das crianças da vida cotidiana. O cartunista reconhece que "se distraiu" por muito tempo ao fato da inclusão social, mas, quando os debates vieram à tona, percebeu a importância de incrementar crianças com necessidades especiais nas histórias, o que lhe rendeu prêmios e homenagens, inclusive pelo Senado Federal. 
de neutralização. Estes sons ocorrem em ambientes fonéticos específicos, que são neutralizados pelo código escrito (Figura 6).

Figura 6: Esquema da representação das consoantes líquidas no português por contextos

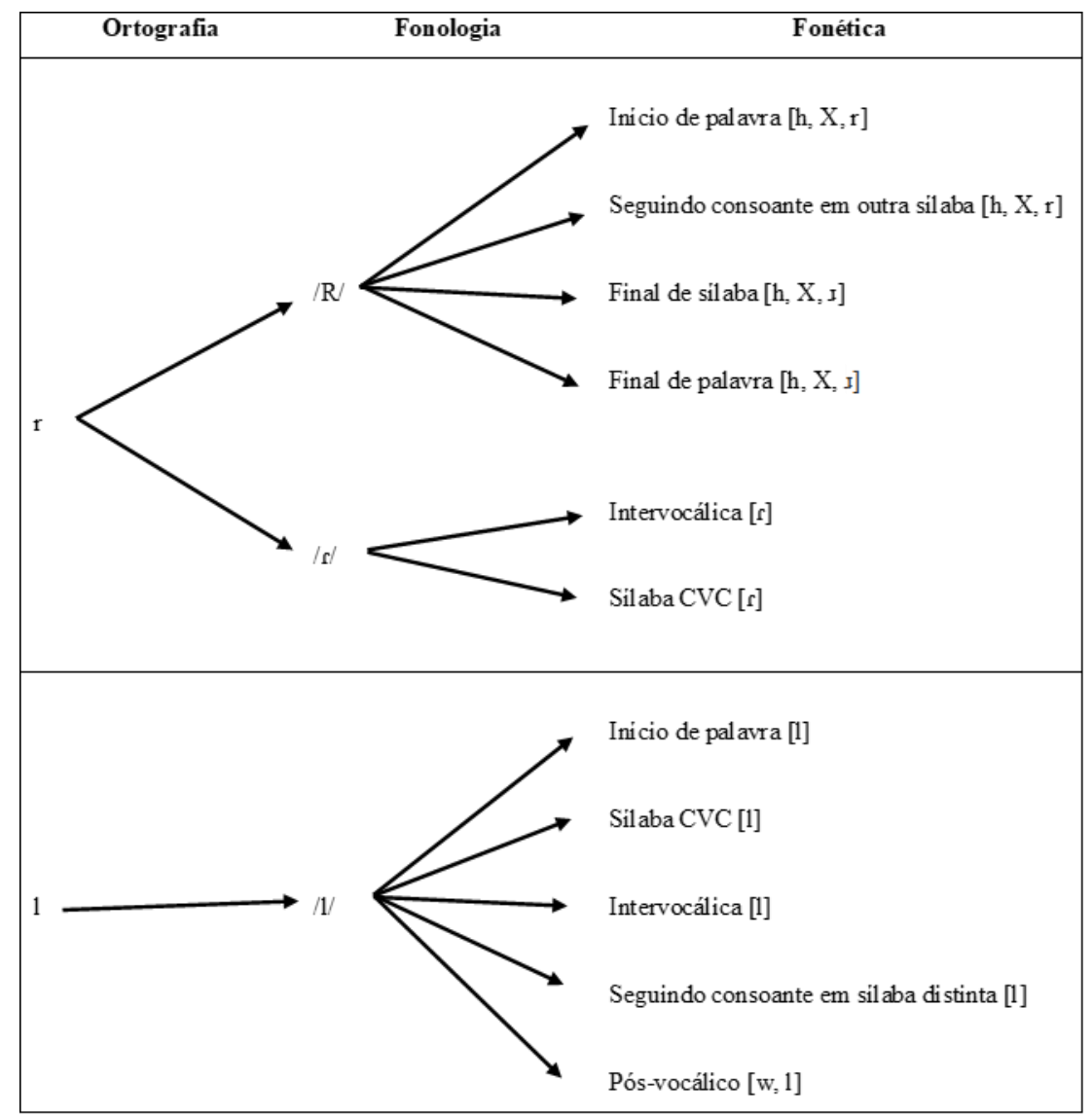

Fonte: Silva (2005).

$\mathrm{Na}$ escrita, as letras " $\mathrm{r}$ " e "l" representam sons com particularidades articulatórias distintas. Por exemplo, escrevemos com "r" a letra inicial da palavra "rato" e a consoante intervocálica em "caro", ou seja, um mesmo signo escrito representando fonemas distintos. Em início de palavra, o /R/ pode ter três realizações fonéticas $[\mathrm{h}, \mathrm{X}, \mathrm{r}]$, a depender da região dialetal do falante, diferentes do $/ \mathrm{f} /$, que ocorre categoricamente como [r] em ataque silábico e em ambiente intervocálico. Do mesmo modo, o "l" ortográfico representa, no nível da escrita, o fonema /1/, que também tem realizações distintas, a depender do contexto. Em início de palavra, a realização lateral alveolar, como em ['la.tə] é categórica, mas, em contexto pós-vocálico, o /1/ apresenta dois alofones [w,l], dos quais somente um apresenta traços articulatórios que permitem a neutralização, que, no entanto, é pouco produtivo no português brasileiro atual (mas ainda o é no português europeu). $\mathrm{O}$ glide velar $[\mathrm{w}]$ tem propriedades articulatórias diferentes das da aproximante lateral, e, por conseguinte, das líquidas. Assim, intercambiar as letras " $\mathrm{r}$ " e "l" livremente, 
como fez o Ministro da Educação em sua postagem, incorre em desconsiderar as propriedades articulatórias das consoantes líquidas que possibilitam a neutralização.

Cebolinha troca $\mathrm{R}$ pelo $\mathrm{L}$ em contexto intervocálico (cérebro $\sim$ céleblo, coragem $\sim$ colagem, teria $\sim$ telia $)$ e em ataque complexo (pra $\sim$ pla, cérebro $\sim$ céleblo). Mas, a personagem não troca $\mathrm{R}$ por $\mathrm{L}$ em coda silábica (embora o faça em início de palavra (rápido lápido), incorrendo também em inconsistência na sua tentativa de representação de um distúrbio como estratégia de inclusão).

Figura 7: Tirinha do Cebolinha
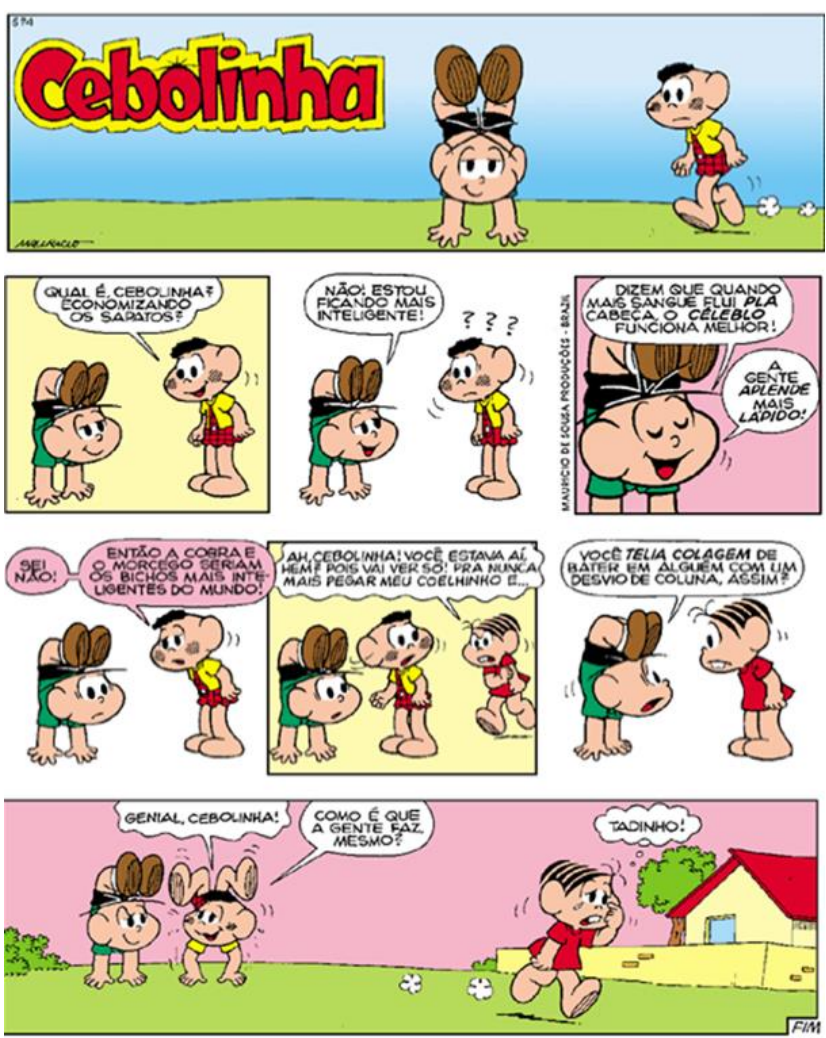

Fonte: <http://aee2013helena.blogspot.com/2013/12/descricao-e-audiodescricao.html>.

Em início de palavra, no português, o / R/ pode ser realizado como [h, $\mathrm{X}, \mathrm{r}]$. Assim, a alternância com a consoante lateral / $/$ / só é possível por proximidade articulatória em variedades de fala em que a vibrante alveolar [r] pode ocorrer em início de palavra, e que, portanto, se aproxima da consoante lateral do ponto de vista articulatório. No português brasileiro, este traço dialetal é muito restrito, sendo condicionado por questões geográficas relativas ao sul do país em casos de contato linguístico com línguas de imigração (BRESCANCINI; MONARET'TO, 2008), não sendo verossímil com um personagem urbano mesmo que represente a fala de uma criança com dislalia. 
Mas, a fala do Cebolinha é sensível à realização de /R/ em coda silábica. No português brasileiro, o cancelamento do / R/ em coda em verbos ocorre indistintamente quanto às regiões ou perfis sociais, num quadro de mudança em progresso (MONARETTO, 2002). Assim, não há justificativa fonológica para a alternância entre $\mathrm{R}$ e L nesse ambiente neste tipo de item, e na fala do Cebolinha, temos bater (Figura 7). O Ministro da Educação desconsiderou esse barramento e escreveu em sua postagem palavras como saiL, seL, dominaL.

Em que pese a inconsistência, a motivação subjacente à troca do $\mathrm{R}$ pelo $\mathrm{L}$ na representação da fala de Cebolinha está relacionada ao propósito de inclusão e diversidade, com a manipulação do traço linguístico para compor o personagem com distúrbio de linguagem. Além de trocar R por L, outra característica que compõe o personagem é a perseguição por um plano conspiratório, traço que também é acionado na postagem do Ministro da Educação.

\subsection{CHINÊS E A TROCA DO R PELO L}

Estereótipos são associações e crenças sobre características e atributos de um grupo e de seus membros que formatam o modo como as pessoas pensam sobre e respondem ao grupo (DOVIDIO et al., 2010). Estereótipos são construídos e precisam ser ativados; o estereótipo de que chineses que falam português como segunda língua trocam $\mathrm{R}$ por $\mathrm{L}$ é amplamente difundido e é subjacente a memes e piadas que são compartilhadas, curtidas e comentadas por milhares de pessoas em redes sociais (Figura 8).

Figura 8: Memes relacionados à representação da fala de asiáticos em português
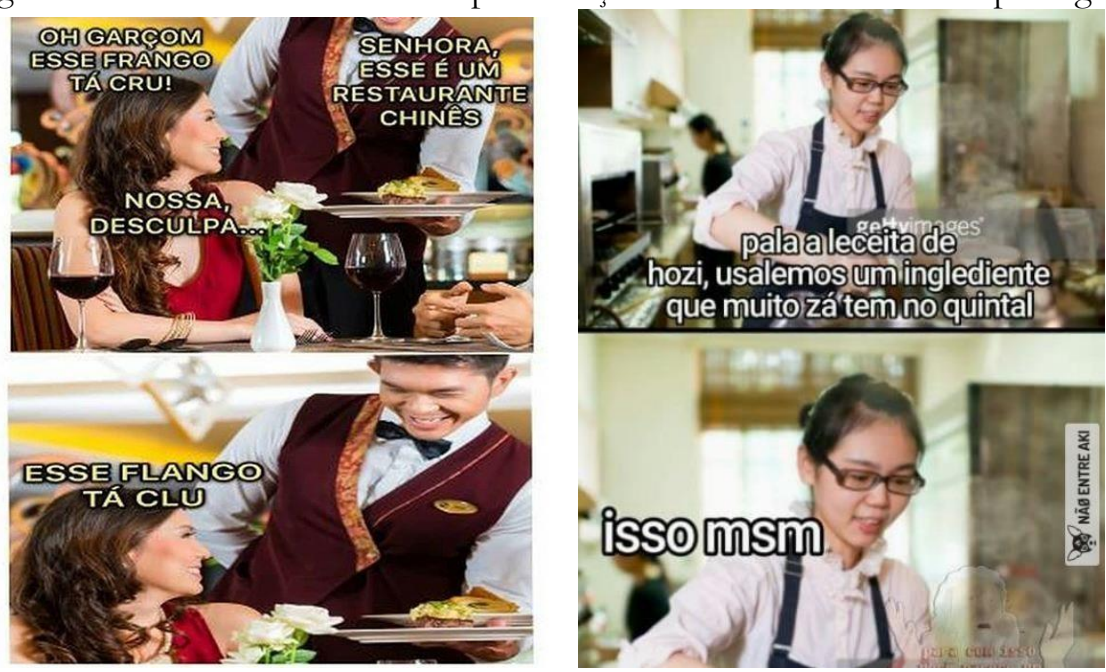

Fonte: <https://twitter.com/coaleatorias/status/1063467747730964481?lang=fi>.

A associação, "deliberadamente elaborada", conforme a nota da Embaixada da China no Brasil, entre a evocação da crença de que ocorre troca R por L por asiáticos falantes de português e a conspiração de disseminação da COVID-19 pelo mundo feita 
na postagem do Ministro da Educação sequer é inédita. Um meme postado em 24 de março deste ano na página Humor de Crente, na rede social Facebook (<https://www.facebook.com/humordecrente/), já explorava esta associação $>)^{5}$.

Figura 9: Postagem da página Humor de Crente no Faceboook, de 24 de março de 2020

\section{Tudo comecou com esse tapa}

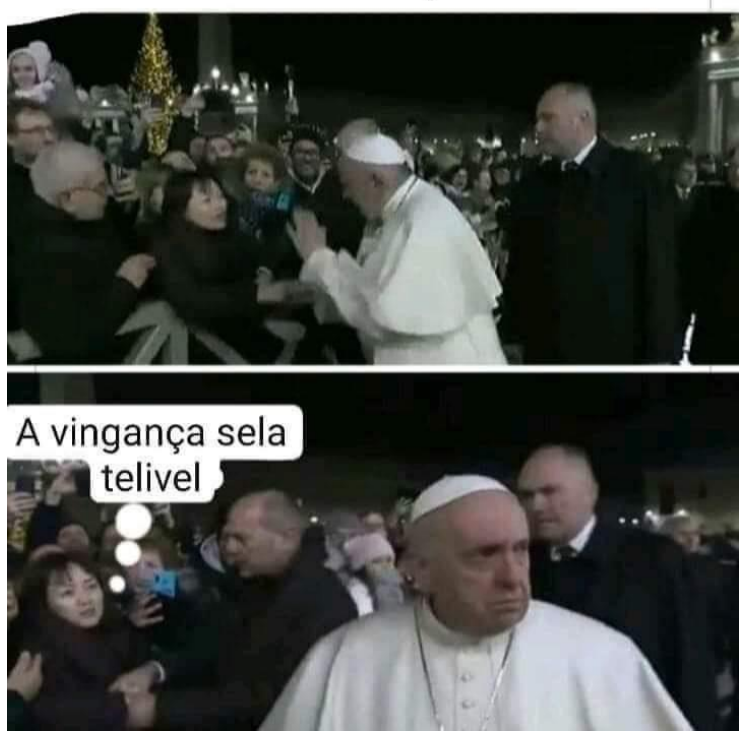

Fonte: Facebook.

Os estudos de aquisição em segunda língua evidenciam que a língua nativa interfere diretamente no processo de aprendizagem da nova língua. Apesar de muitas pessoas adquirirem e utilizarem apenas uma língua durante toda vida, o número de falantes de uma segunda língua vem aumentando de maneira expressiva. No caso dos chineses, especificamente, Zhou (2017) argumenta que intensificação das relações econômicas, políticas e culturais entre a China e os países de língua portuguesa tem incentivado a procura da aprendizagem do português por alunos chineses em todo o país. Estas pessoas são motivadas por necessidade, seja técnica ou profissional, ou por interesses pessoais de inserção cultural onde a língua portuguesa é falada (GRIFFIN, 2011; GARDNER; LAMBERT, 1972). A partir do momento em que começa a adquirir um novo sistema linguístico distinto do da língua materna, o aprendiz começa a deparar-se com problemas

\footnotetext{
${ }^{5}$ No dia 31 de dezembro de 2020, o Papa Francisco foi flagrado dando um tapa em uma mulher, com traços asiáticos (não há informação sobre a sua nacionalidade). Segundo site oficial do Vaticano, "o papa foi puxado bruscamente, o que provocou forte dor no braço". No dia seguinte, o Papa se desculpou pelo mau exemplo: < https://www.vaticannews.va/pt/papa/news/2020-01/papa-francisco-angelus-01-janeiro2020.html>.
} 
para superar os efeitos do conhecimento sonoro da L1 (FLEGE, 1995; BLANK; ZIMMER, 2009).

Há autores que propõem substituir o conceito de “aquisição de segunda língua” por "aprendizagem de segunda língua", por considerarem processos distintos. A aquisição da língua é um processo que diz respeito exclusivamente às crianças e está intimamente relacionada a processos de desenvolvimento biológico ou naturais. Já a aprendizagem de uma segunda língua diz respeito a um processo divergente, no qual podem participar crianças e adultos, com a presença de um professor em um processo formal, com exercícios gramaticais e conversacionais (MARTÍN, 2004). A diferença entre os dois processos é apresentada no Quadro 1.

Figura 10: Diferença entre aquisição de língua materna e aprendizagem de segunda língua

AQUISIÇÃO DE LÍNGUA MATERNA

\section{SUCESSO OU EXXITO \\ ERROS \\ INSTRUÇÃO \\ FORMAL}

ESPAÇO/TEMPO

\section{OBJETIVO}

Em condições normais, a criança sempre o consegue em todos os casos.

O mundo, nos primeiros anos das crianças, é o aqui e agora. Logo, existem parâmetros limitados que satisfazem suas necessidades de comunicação.

A criança não tem medo de cometer erros.

A criança não a necessita para chegar ao nível de um nativo em sua língua materna.

Nas crianças, o objetivo já está predeterminado por sua faculdade de aprender a falar. E é isso que faz com que elas se comuniquem.
APRENDIZAGEM DE SEGUNDA LÍNGUA

Limita-se a uma pequena minoria. Existe também uma grande variedade na velocidade de aprendizagem, e muitos aprendizes progridem aquém da meta esperada.

$\mathrm{O}$ adulto tende a comunicar ideias mais complexas, inclusive quando os recursos que possui da L2 ainda não dão conta da atividade.

$\mathrm{O}$ adulto evita certas estruturas na L2 exatamente por medo de errar. $\mathrm{O}$ adulto precisa de instrução formal, até porque ele não consegue captar certas características da língua por mera exposição a ela.

Os objetivos são diferentes, dependendo de cada pessoa. $\mathrm{O}$ adulto pode centrar-se em aprender a L2 para ler textos, ou para atender a seus clientes, ou para comunicarse numa viagem, etc.

Fonte: Martín (2004, p. 266).

Uma diferença que deve ser levada em consideração entre os aprendizes de segunda língua diz respeito à influência da língua materna. Esta diferença é perceptível no desempenho fonológico. A semelhança entre as origens das línguas pode desencadear um conforto no aprendiz. Por exemplo, um brasileiro falante de português pode ter mais facilidade e conforto em aprender espanhol, porque ambas as línguas compartilham da mesma origem e apresentam fonemas e sistemas fonológicos semelhantes. Em contrapartida, um chinês aprendendo português terá mais fonemas a aprender do que um espanhol.

O português e o mandarim, língua oficial da China, têm sistemas fonológicos distintos (ZHOU, 2017). Há fonemas que existem em uma língua e não na outra: o mandarim não apresenta o segmento consonantal [r], mas dispõe do [1], segmento que 
está no mesmo modo de articulação, isto é, referem-se ao grupo das consoantes alveolares (SILVA, 2005).

Figura 11: Comparativo dos sistemas fonéticos do Português (SILVA, 2005) e do Chinês Mandarim

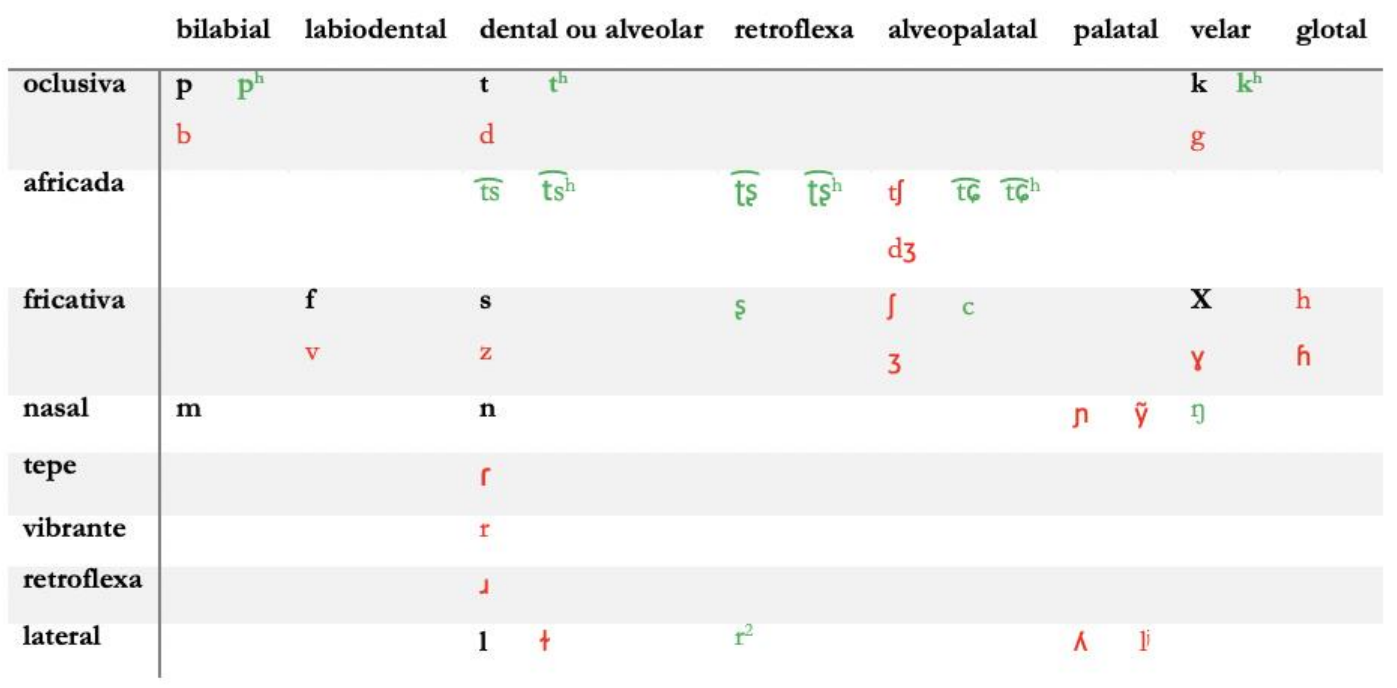

Vermelho $=$ português brasileiro (SILVA, 2005)

Verde $=$ chinês mandarim (DUANMU, 2005).

Preto $=$ comum aos dois sistemas fonéticos

Fonte: Elaboração própria baseado em Silva (2005) e Duanmu (2005).

A produção de sons não nativos tem frequentemente base na percepção sonora (FLEGE, 1995; OLIVEIRA, 2016), havendo interferência do sistema fonológico da língua materna no processo de aprendizagem da segunda língua. Ao tentar realizar os sons da língua alvo que não existem no inventário fonológico da sua língua nativa, os falantes intuitivamente realizam o som mais próximo a partir de similaridades articulatórias (ZHOU, 2017). Isso é explicado por condicionamentos fisiológicos do sistema fonador, e porque os falantes não nativos mobilizam os conhecimentos já existentes no seu sistema linguístico (GASS; SELINKER, 2008). Além disso, os aprendizes exploram as informações contidas no input, cuja hipótese afirma que primeiro se adquire o significado e, como resultado, se adquire a estrutura, ou seja, o falante não está preocupado em "como" dizer, mas com "o que" dizer (FIGUEIREDO, 1995).

Os chineses aprendizes de português têm dificuldade na articulação para produção do /R/ (MARTINS, 2008; OLIVEIRA, 2016) por não encontrarem correspondente na língua nativa: como o mandarim não apresenta o segmento consonantal [ $\mathrm{r}$ ], presente no português, mas dispõe do [1], segmento que está no mesmo modo de articulação, isto é, referem-se ao grupo das consoantes alveolares (SILVA, 2005), os falantes realizam a troca das consoantes por similaridade articulatória (Figura 11). 
Se num primeiro momento o fluxo de migração chinesa no Brasil se concentrou em alguns centros urbanos, em núcleos relativamente fechado, nos últimos tempos, com a presença do comércio chinês, com lojas e lanchonetes especialmente, avançando e interiorizando no Brasil, o contato com os brasileiros é intensificado, gerando a estereotipia, aos mesmos moldes do que acontece em língua materna. Do mesmo modo que são construídos os estereótipos linguísticos regionais, a partir de traços linguísticos salientes, como baianos falam devagar, paulistas falam apressado, mineiros comem as palavras, etc. (FREITAG et al., 2015, 2016), os chineses falantes de português também são identificados por um traço linguístico, no caso, a troca do / $/$ pelo /1/.

\section{CONCLUSÃO}

Demonstramos como a manipulação de um traço linguístico pode evocar discriminação e preconceito, não só em relação à origem, mas em relação ao arraigado preconceito de classe e raça que existe no Brasil, e que é materializado na língua. Além de contribuir para o desvelamento da postura preconceituosa do Ministro da Educação na postagem em questão, relevamos a importância da pesquisa em ciências humanas em específico, e da pesquisa básica em geral para o combate ao preconceito e à discriminação (ciência básica) para o campo aplicado e interdisciplinar, mostrando o uso da língua para o preconceito.

Ao comparar a fala dos chineses com a fala do Cebolinha, a criança que fala "errado", em termos indexicais, com o objetivo de demonstrar a sua superioridade, configura-se como uma apropriação, com viés xenófobo. Fica assim explicitado o preconceito objeto de punição da Lei 7.716, de 5 de janeiro 1989: "Serão punidos, na forma desta Lei, os crimes resultantes de discriminação ou preconceito de raça, cor, etnia, religião ou procedência nacional" (BRASIL, 1989). Em sua postagem, o Ministro da Educação incorre em crime, sendo passível da punição prevista pelo artigo 20 da Lei supracitada: "Praticar, induzir ou incitar a discriminação ou preconceito de raça, cor, etnia, religião ou procedência nacional” (BRASIL, 1989).

Uma das características do português de arremedo, segundo Silva (2019) é que o seu uso é intencional por pessoas que não adotam essas variantes com frequência, no seu dia a dia. Não só a postagem que arremeda a fala dos chineses deveria ser objeto de inquérito da Procuradoria Geral da República, mas também a outra postagem, que arremeda a fala de milhões de brasileiros que discrimina quem não teve acesso à escolarização formal e a toda ascensão social que a escolarização ainda possibilita. Tão criminosa quanto a discriminação e o preconceito contra os chineses é o Ministro da Educação discriminar os brasileiros que não dominam a variedade estabelecida como "a variedade".

A liberdade de expressão poderia ser evocada por um cidadão comum, mas o Código de Conduta da Alta Administração Federal, de 21 de agosto de 2000, preconiza que as autoridades públicas devem pautar-se "pelos padrões da ética, sobretudo no que diz respeito à integridade, à moralidade, à clareza de posições e ao decoro, com vistas a motivar o respeito e a confiança do público em geral” (BRASIL, 2000), o que foi infringido pelo Ministro da Educação. Esperamos que os argumentos científicos aqui 
evocados sejam considerados na consecução do inquérito da Procuradoria Geral da República.

\section{AGRADECIMENTOS}

Agradecemos a Bruno Felipe Marques Pinheiro, pela leitura atenta e contribuições para o aprimoramento da versão final deste texto; Silas Coutinho de Faria Alves, pelas contribuições à consistência das leis evocadas, e Silvana Silva de Farias Araújo, pelo envio de material imagético incorporado à análise.

\section{REFERÊNCIAS}

ABRAÇADO, J.; MARTINS, M. A. (Ed.). Mapeamento sociolinguistico do português brasileiro. Editora Contexto, 2015.

ADORNO, T.W. et al. The authoritarian personality. New York: Harper, 1950.

ALLPORT, G.W. The nature of prejudice. 3. ed. Wokingham: Addison-Wesley, 1979.

AMARAL, A. O Dialeto caipira. São Paulo: HUCITEC/Secretaria da Cultura, 1976.

BILLIG, M. Racismo, prejuicios y discriminacion. In: MOSCOVICI, S. (Ed.). Psicologia Social II: Pensamiento y vida social. Barcelona: Paidós, 1984, p. 575-600.

BLANK, C. A.; ZIMMER, M. C. A transferência fonético-fonológica L2 (francês)-L3 (inglês): um estudo de caso. Revista de Estudos da Linguagem, v. 17, n. 1, p. 207-233, 2009.

BORTONI-RICARDO, S. M. Educação em língua materna: a sociolinguística na sala de aula. São Paulo: Parábola Editorial, 2004.

BRASIL. Código de Conduta da Alta da Administração Federal, de 21 de agosto de 2000. Disponível em: <http://www.planalto.gov.br/ccivil_03/codigos/codi_conduta/cod_conduta.htm>. Acesso em: 20 de abr. 2000.

BRASIL. Constituição da República Federativa do Brasil de 1988. Disponível em: $<$ http://www.planalto.gov.br/ccivil_03/constituicao/constituicao.htm>. Acesso em: 19 abr. 2020.

BRASIL. Lei 12.965, de 23 de abril de 2014. Estabelece princípios, garantias, direitos e deveres para 0 uso da Internet no Brasil. Disponível em: <http://www.planalto.gov.br/ccivil_03/_ato2011-2014/2014/lei/112965.htm>. Acesso em: 19 abr. 2020.

BRASIL. Lei 7.716, de 5 de janeiro 1989. Define os crimes resultantes de preconceito de raça ou de cor. Disponível em: <http://www.planalto.gov.br/ccivil_03/leis/17716.htm>. Acesso em: 19 abr. 2020 . 
BRASIL. Lei 9.610, de 19 de janeiro de 1998. Altera, atualiza e consolida a legislação sobre direitos autorais $e$ dá outras providências. Disponível em: <http://www.planalto.gov.br/ccivil_03/leis/19610.htm>. Acesso em: 19 abr. 2020.

BRESCANCINI, C.; MONARETTTO, V. N. de O. Os róticos no sul do Brasil: panorama e generalizações. Signum, n. 11, p. 51-66, dez. 2008.

CASTRO, V. S. O "r caipira" em Mato Grosso do Sul-estudo baseado em dados do ALMS, Atlas linguístico do Mato Grosso do Sul. Estudos Linguísticos, v. 42, n. 1, p. 566575, 2013.

COAN, M.; FREITAG, R. M. K. Sociolinguística variacionista: pressupostos teóricometodológicos e propostas de ensino. Dominios de Lingu@gem, v. 4, n. 2, p. 173-194, 2010. COSTA, L. T. da. 2011. 173 f. Abordagem dinâmica do rotacismo. Tese (Doutorado em Linguística) - Setor de Ciências Humanas, Letras e Artes, Universidade Federal do Paraná, 2011. $173 \mathrm{f}$.

COSTA, L. T. da. Análise variacionista do rotacismo. Revista Virtual de Estudos da Linguagem - ReVEL, v. 5, n. 9, p.1-29, 2007.

COSTA, L. T. da. Fenômenos variáveis e variantes líquidas produzidas no ataque complexo. Acta Scientiarum, Language and Culture, v. 35, n. 2, p. 179-186, 2013.

DOVIDIO, J. F. et al. Prejudice, stereotyping and discrimination: Theoretical and empirical overview. In: DOVIDIO, J.F. et al. (Eds.). The SAGE handbook of prejudice, stereotyping and discrimination. Califórnia: SAGE, 2010, p. 3-29.

DUANMU, S. Chinese (Mandarin): phonology. In: BROWN, K. (Ed.) Encyclopedia of Language and Linguistics, 2nd Edition. Oxford, UK: Elsevier Publishing House, p. 351-355, 2005.

EAGLY, A. H.; DIEKMAN, A. B. What is the problem? Prejudice as an attitude-incontext. In: DOVIDIO, J. F.; GLICK, P.; RUDMAN, L. A. (Eds.). On the Nature of Prejudice: Fifty Years After Allport. Oxford: Blackwell, 2008, p. 19-35.

FIGUEIREDO, F. J. Q. de. Aquisição e aprendizagem de segunda língua. Signótica, v.3, p. 39-57, 1995.

FLEGE, J. E. Second language speech learning: Theory, findings, and problems. Speech perception and linguistic experience: Issues in cross-language research, v. 92, p. 233-277, 1995.

FREITAG, R. M. K. et al. Como o brasileiro acha que fala? Desafios e propostas para a caracterização do" português brasileiro". Signo y seña, n. 28, p. 65-87, 2015.

FREITAG, R. M. K. et al. Como os brasileiros acham que falam? Percepções sociolinguísticas de universitários do Sul e do Nordeste. Todas as Letras-Revista de Lingua e Literatura, v. 18, n. 2, 2016. 
FREITAG, R. M. K. et al. Vamos prantar frores no grobo da terra: estudando o rotacismo nas séries iniciais da rede municipal de ensino de Moita Bonita/SE. RevLet-Revista Virtual de Letras, v. 2, p. 17-31, 2010.

FREITAG, R. M. K. Sociolinguística no/do Brasil. Cadernos de Estudos Lingüísticos, v. 58, n. 3, p. 445-460, 2016.

GARDNER, R.; LAMBERT, W. Attitudes and motivation in second language learning. Rowley: Newbury House, 1972.

GASS, S. M.; SELINKER, L. Second language acquisition: An introductory course. Routledge, 2008.

GHANDOUR, H.; KADDAH, F. Factors affecting stimulability of erred sounds in common types of dyslalia. Egyptian Journal of Ear, Nose, Throat and Allied Sciences, v. 12, n. 1, p. 61-67, 2011.

GIORDANI, M. N. P. O rotacismo em final de sílaba. Filologia e Linguística Portuguesa, v. 7, n. 7, p. 129-134, 2005.

GRIFFIN, K. Lingüistica aplicada a la enseñanza del español como 2/L. 2 ed. Madrid: Arco Libros, 2011.

HILL, J. H. Language, race, and white public space. American anthropologist, v. 100, n. 3, p. 680-689, 1998.

INSTAURAÇÃO DE INQUÉRITO. MINISTÉRIO PÚBLICO FEDERAL/PROCURADORIA GERAL DA REPÚBLICA. Inquérito 0004827, de 10 de abril de 2020. Disponível em: <https://www.conjur.com.br/dl/pgr-inquerito-weintraubracismo-chineses.pdf $>$. Acesso em: 15 abr. 2020.

JONES, J. M. Racismo e preconceito. São Paulo: Edgard Blücher, 1972.

LIMA, M. E. O.; VALA, J. As novas formas de expressão do preconceito e do racismo. Estudos de Psicologia, v. 9, n.3, 2004, p. 401-412.

LIPPMANN, W. Public opinion. Nova York: Harcourt Brace, 1922.

MARTÍN, J. M. La adquisición de la lengua materna (L1) y el aprendizaje de una segunda lengua (L2)/lengua extranjera (LE): procesos cognitivos y factores condicionantes. In: LOBATO, S. J.; GARGALLO, I. S. Vademécum para la formación de profesores: enseñar español como segunda lengua (L2)/lengua extranjera (LE). Madrid: SGEL, 2004.

MARTINS, M. O português dos chineses em Portugal - O caso dos imigrantes da área do comércio e restauração em Águeda. 2008. Dissertação (Mestrado em Estudos Portugueses), Universidade de Aveiro, 2008.

MONARETTO, V. N. de O. A vibrante pós-vocálica em Porto Alegre. In: BISOL, L.; BRESCANCINI, C. (Org.). Fonologia e variação: recortes do Português Brasileiro. Porto Alegre: EDIPUCRS, 2002, p. 253-268.

NOH, A. I. C. et al. Dislalia asociada a hábitos orales. Oral, v. 13, n. 41, p. 865-869, 2012. 
OCHS, E. Indexing gender. New York: Cambridge University Press, 1992.

OLIVEIRA, D. M. de. Percepção e produção de sons consonânticos do português europen por aprendentes chineses. 2016. Dissertação (Mestrado em Português Língua Não Materna), Universidade do Minho, 2016.

PAIVA, M. da C. de; SCHERRE, M. M. P. Retrospectiva sociolingüística: contribuições do PEUL. DELTA: Documentasaão de Estudos em Lingüistica Teórica e Aplicada, v. 15, n. SPE, p. 201-232, 1999.

PINHEIRO, B. F. M.; FREITAG, R. M. K. Estereótipos na concordância de gênero em profissões: efeitos de frequência e saliência. Linguística, 2020.

REIS, G. F. M. dos. Cravícula e carcanhá: a incidência do rotacismo no falar maranhense. Revista Littera, v. 1, nº 1, p. 33-40, 2010.

RODRIGUES, A.; ASSMAR, E. M. L.; JABLONSKI, B. Psicologia Social. 18. ed. Petrópolis/RJ: Vozes, 1999.

ROMANO, V. P.; FONSECA, C. G. Uma abordagem sociodialetológica do fenômeno do rotacismo no município de Itajubá-MG. Web-revista sociodialeto, v. 6, n. 16, 2015.

RONCARATI, C.; ABRAÇADO, J. Português brasileiro II: contato lingüístico, heterogeneidade e história. Rio de Janeiro: 7 Letras, 2008.

RONCARATI, C.; ABRAÇADO, J. Português brasileiro. Rio de Janeiro: 7 Letras, 2003.

SCHERRE, M. M. P. Padrões sociolinguísticos do português brasileiro: a importância da pesquisa variacionista. Tabuleiro de Letras, n. 4, 2012.

SIBLEY, C. G.; BARLOW, F. K. What is prejudice? An introduction. In: BARLOW, F. K.; SIBLEY, C. G (Eds.). The Cambridge Handbook of the Psychology of Prejudice: Concise Student Edition. Cambridge: Cambridge University Press, 2008, p. 1-14

SILVA, A. J. B. da. Português de arremedo: um lado do preconceito linguístico no Brasil. Cadernos de Estudos Linguisticos, Campinas, v.61, p. 1-19, 2019.

SILVA, T. B.; SIMIONI, T. O personagem Chico Bento como recurso didático e o que ele revela sobre os conhecimentos de variação linguística de professores e futuros professores. Guavira Letras, v. 11, n. 21, 2016.

SILVA, T. C. Fonética e Fonologia do Português: roteiro de estudos e guia de exercícios. 10. ed. São Paulo: Contexto, 2005.

SOUZA, G. de L.; SILVA, R. M. da C.; COUTINHO, D. J. G. Dislexia e dislalia: necessidades e possibilidades na prática inclusiva. Brazilian Journal of Development, v. 5, n. 12, p. 32009-32018, 2019.

STANGOR, C. Stereotypes and Prejudice: Essential Readings. Philadelphia, PA: Psychology Press, 2000. 


\section{Revista

STANGOR, C.; LANGE, J. Mental representation of social groups: advances in understanding stereotypes and stereotyping. Advances in experimental social psychology, v. 26, p. 357-416, 1994.

STEPHAN, W. G.; STEPHAN, C. W. An Integrated Threat Theory of Prejudice. In: OSKAMP, S. (Ed.). Reducing prejudice and discrimination. Nova Jersey: Lawrence Erlbaum, 2000, p 23-45.

ZANNA, M., P.; REMPEL, J. K. Attitudes: A new look at an old concept. In: BAR-TAL, D.; KRUGLANSKI, A. W.(Ed.). The social psychology of knowledge. Cambridge, UK: Cambridge University Press, 1988, p. 315-334.

ZHOU, C. Contributo para o estudo da aquisição das consoantes líquidas do português europeu por aprendentes chineses. 2017. Dissertação (Mestrado em Linguística), Universidade de Lisboa, 2017.

Recebido em: 21/04/2020

Aprovado em: 27/04/2020

Publicado em: 30/04/2020 